\title{
Peningkatan Hasil Belajar IPS Tentang Koperasi dengan Menggunakan Model Pembelajaran Kooperatif Tipe Student Teams Achievement Division pada Siswa Kelas IV DI SDN. No. 031/XI Kampung Dalam Tahun 2016/2017
}

\author{
Enirisda ${ }^{1}$ \\ Guru di SDN. No. 031/XI Kampung Dalam ${ }^{1}$ \\ Kecamatan Hamparan Rawang, Kota Sungai Penuh, Provinsi Jambi
}

\begin{abstract}
This classroom action research aims to improve the learning outcomes of fourth grade students of SDN. No. 031/XI Kampung Dalam year 2016/2017 on social studies subjects about cooperatives using cooperative learning model type Student Teams Achievement Division (STAD). This study was conducted in two cycles (Cycle I and Cycle II). Each cycle is done with two meetings and one meeting for evaluation. One cycle consists of four activities, namely planning, implementation, observation, and reflection. The study involved 10 fourth grade students year 2016/2017 at SDN. No. 031 / XI Kampung Dalam, Hamparan Rawang Subdistrict, Sungai Penuh City, Jambi Province. Data was collected by observation and test. Data was analyzed by descriptive analysis and simple statistical test. The results showed that student learning activities improved. All students have heard the teacher's explanation and formed a heterogeneous group. Most students have also been able to work together in groups, answer quizzes, and deliver results. In addition, the use of STAD type cooperative learning model succeeded in improving student learning outcomes which are seen from the improvement of the average score and learning mastery. The average value increased from 53,0 (before action) to 66,0 in cycles I and 79,0 in cycle II. Learning mastery also increased from 40,0\% (before action) to 60,0\% in cycle I and again increased to 90,0\% in cycle II. Thus, this study concluded that the implementation of cooperative learning model type STAD can improve learning outcomes of fourth grade students at SDN. No. 031/XI Kampung Dalam year 2016/2017 on Social Sciences subjects.
\end{abstract}

Keywords: classroom action research, elementary school, learning outcomes, social sciences, STAD

\section{PENDAHULUAN}

Pendidikan merupakan salah satu cara untuk mempersiapkan sumber daya manusia yang berkualitas (Umiarso, 2011). Undang-Undang Nomor 20 tahun 2003 tentang Sistem Pendidikan Nasional Bab I Pasal 1 (ayat 1) mengartikan pendidikan sebagai usaha sadar dan terencana untuk mewujudkan suasana belajar dan proses pembelajaran agar peserta didik secara aktif mengembangkan potensi dirinya untuk memiliki kekuatan spiritual keagamaan, pengendalian diri, kepribadian, kecerdasan, akhlak mulia, serta keterampilan yang diperlukan dirinya, masyarakat, bangsa, dan negara. Oleh karenanya peningkatan kualitas penyelenggaraan diperlukan agar tujuan dari pelaksanaan pendidikan dapat tercapai dengan baik.

Salah satu tahapan penting pendidikan bagi seorang anak berada pada fase usia sekolah yaitu Sekolah Dasar (SD). Keberhasilan pendidikan di SD menentukan keberhasilan pendidikan di tahapan selanjutnya yaitu SMP, SMA, dan Perguruan Tinggi. Salah satu mata pelajaran yang wajib diikuti oleh siswa adalah mata pelajaran Ilmu Pengetahuan Sosial (IPS). Mata pelajaran ini mengarahkan, membimbing, dan membantu siswa untuk menjadi warga 
negara Indonesia dan warga dunia yang demokratis. Mata pelajaran IPS tidak hanya menuntut siswa untuk memahami konsep yang telah dipelajari di sekolah, tetapi juga harus mampu menerapkan konsep tersebut dalam kehidupan seharihari. Mata pelajaran IPS mengajarkan siswa mengenai pengetahuan sosial. Mata pelajaran ini bertujuan untuk mengenal konsep-konsep yang berkaitan dengan kehidupan masyarakat dan lingkungannya; memiliki kemampuan dasar untuk berfikir logis dan kritis, rasa ingin tahu, inkuiri, memecahkan masalah, dan keterampilan dalam kehidupan sosial; memiliki komitmen dan kesadaran terhadap nilainilai sosial dan kemanusiaan; dan memiliki kemampuan berkomunikasi, bekerjasama dan berkompetisi dalam masyarakat yang majemuk, di tingkat lokal, nasional, dan global (Sapriya, 2009).

IPS memegang peranan penting dalam membekali siswa mengenai pengetahuan sosial. Oleh karenanya, mata pelajaran ini seharusnya menjadi pelajaran yang disenangi dan bermakna bagi siswa. Pembelajaran yang menyenangkan akan menyebabkan siswa terlibat secara aktif. Dengan terlibat aktif, maka siswa akan mempunyai pemahaman yang kuat terhadap materi. Oleh karena itu, guru dituntut untuk dapat mengelola proses belajar mengajar dengan memiliki kemampuan dalam memilih model dan metode pembelajaran yang sesuai dengan tujuan kurikulum dan potensi yang dimiliki oleh peserta didik. Hal ini didasari oleh asumsi bahwa ketepatan guru dalam memilih model dan metode pembelajaran akan berpengaruh terhadap hasil belajar peserta didik.

Hasil pengamatan mengidentifikasi beberapa masalah dalam pembelajaran IPS di kelas IV SDN. No. 031/XI Kampung Dalam yaitu kegiatan pembelajaran berpusat pada guru yang menyebabkan siswa tidak berperan aktif dalam kegiatan pembelajaran. Siswa kurang memperhatikan penjelasan materi pelajaran IPS. Siswa memilih untuk berbicara dengan teman sebangku, melamun, mencoret buku, dan juga ada siswa yang mengantuk. Hal ini dapat terjadi karena kondisi pembelajaran yang monoton dan searah. Dalam mengajar, guru menggunakan metode konvensional yaitu ceramah dan tanya jawab. Akibatnya, hasil belajar siswa pada mata pelajaran IPS tergolong rendah. Hasil tes penjajakan menunjukkan bahwa nilai rata-rata siswa pada mata pelajaran IPS adalah sebesar 53,0 dengan ketuntasan belajar sebesar $40,0 \%$. Hasil ini menunjukkan bahwa hanya ada empat dari sepuluh siswa yang nilainya memenuhi Kriteria Ketuntasan Minimal (KKM) kompetensi dasar untuk mata pelajaran IPS yaitu sebesar 62,0.

Hasil belajar siswa merupakan salah satu indikator keberhasilan proses belajar mengajar di kelas. Hasil belajar dapat didefinisikan sebagai hasil dari suatu interaksi tindak belajar dan tindak mengajar (Dimyati dan Mudjiono, 2013). Hasil belajar yang rendah mengindikasikan bahwa proses belajar mengajar di kelas belum berhasil. Guru perlu menemukan solusi yang tepat untuk mengatasi hal tersebut. Salah satu cara yang dapat dilakukan untuk meningkatkan hasil belajar siswa adalah dengan mengubah model pembelajaran karena model pembelajaran menuntun guru agar dapat melaksanakan pembelajaran secara efektif dalam meningkatkan hasil belajar siswa. Trianto (2007) mengemukakan model pembelajaran adalah kerangka konseptual yang melukiskan prosedur yang sistematis dalam mengorganisasikan pengalaman belajar untuk mencapai tujuan belajar tertentu, dan berfungsi sebagai pedoman bagi para perancang pembelajaran dan para pengajar dalam merencanakan aktivitas belajar mengajar. Dalam penerapannya, model pembelajaran harus dilakukan sesuai dengan kebutuhan siswa, karena masing-masing model pembelajaran 
memiliki tujuan, prinsip, dan tekanan yang berbeda-beda. Rusman (2011) menjelaskan bahwa guru boleh memilih model pembelajaran yang sesuai dan efisien untuk mencapai tujuan pendidikannya.

Salah satu model pembelajaran yang dapat meningkatkan keaktifan siswa pada mata pelajaran IPS adalah model pembelajaran kooperatif tipe Student Team Achievemen Divisions (STAD). Model pembelajaran kooperatif tipe STAD dikembangkan oleh Robert Slavin dan teman-temannya di Universitas John Hopkin (Slavin, 2008). Dalam model ini, guru membagi peserta didik menjadi beberapa kelompok kecil atau tim belajar dengan jumlah anggota setiap kelompok 4 atu 5 orang secara heterogen. Setiap kelompok menggunakan lembar kerja akademik dan saling membantu untuk menguasai materi ajar melalui tanya jawab atau diskusi antar kelompok. Melalui STAD, siswa dilatih untuk bekerjasama, menghargai pendapat teman, dan mengajarkan makna keberagaman kepada siswa. Hal ini sesuai dengan konsep IPS, yakni mencetak siswa menjadi pribadi yang demokratis, mampu bersosialisasi dan bermasyarakat. Berbagai penelitian telah membuktikan bahwa penggunaan model pembelajaran kooperatif tipe STAD dapat meningkatkan hasil belajar siswa Sekolah Dasar pada mata pelajaran IPS (Mangentje, 2013; Darusalam, 2013; Mutalib, 2014; Pantanemo, Saneba, dan Palimbong, 2014; Gusniar, 2014; Jatimah, 2016; Jasman, 2016; Widiyati, 2016).

Pembelajaran kooperatif tipe STAD memungkinkan terciptanya situasi belajar yang menyenangkan, meningkatkan interaksi dan kerjasama siswa baik terhadap kelompoknya maupun terhadap guru, serta menciptakan situsi belajar mengajar yang kondusif. Adanya kompetisi dalam kelompok juga dapat menumbuhkan motivasi belajar siswa yang nantinya berpengaruh terhadap hasil belajar dalam kelompok. Diskusi memfasilitasi siswa untuk dapat berfikir kritis, bekerjasama, saling menyampaikan pendapat, menilai kemampuan dan peranan diri sendiri maupun teman yang lain, mampu menerima perbedaan dan menyumbangkan pikiran untuk memecahkan masalah bersama. Dalam diskusi kelompok siswa akan banyak menemukan perbedaan pandangan yang justru akan melatih mereka untuk dapat menyatukan, meluruskan pendapat yang pada akhirnya akan menemukan konsep yang sama. Dengan demikian, model pembelajaran STAD dapat membantu siswa untuk lebih memahami materi. Berdasarkan pemaparan tersebut, penulis tertarik untuk melakukan penelitian yang berjudul "Peningkatan Hasil Belajar IPS tentang Koperasi dengan Menggunakan Model Pembelajaran Kooperatif Tipe Student Teams Achievement Division pada Siswa Kelas IV di SDN. No. 031/XI Kampung Dalam tahun 2016/2017”. Penelitian ini bertujuan untuk meningkatkan hasil belajar IPS tentang koperasi pada siswa kelas IV di SDN. No. 031/XI Kampung Dalam tahun 2016/2017 dengan menggunakan model pembelajaran kooperatif tipe Student Teams Achievement Division.

\section{METODE PENELITIAN}

Penelitian ini merupakan penelitian tindakan kelas yang dilaksanakan dalam dua siklus (Siklus I dan Siklus II). Penelitian dilakukan di SDN. No. 031/XI Kampung Dalam, Kecamatan Hamparan Rawang, Kota Sungai Penuh, Provinsi Jambi. Kegiatan penelitian terdiri atas penyusunan proposal penelitian, pengumpulan data, pengolahan data, analisis data, dan penyusunan laporan. Penelitian dilakukan sejak bulan Januari sampai dengan bulan Mei tahun 2017.

Subjek dalam penelitian ini adalah siswa kelas IV semester genap tahun pelajaran 2016/2017 di SDN. No. 031/XI Kampung Dalam, Kecamatan Hamparan 
Rawang, Kota Sungai Penuh, Provinsi Jambi. Jumlah subjek yang terlibat dalam penelitian ini adalah 10 orang siswa. Objek dalam penelitian ini adalah peningkatan hasil belajar IPS siswa kelas IV di SDN. No. 031/XI Kampung Dalam.

Data yang dikumpulkan dalam penelitian tindakan kelas ini adalah data primer yaitu berupa data hasil belajar. Hasil belajar yang diukur berdasarkan aktivitas belajar dan hasil belajar siswa pada mata pelajaran IPS khususnya pada materi koperasi. Aktivitas belajar diukur dengan evaluasi belajar jenis nontes yaitu pengamatan atau observasi. Observasi merupakan cara untuk menghimpun data atau bahan-bahan keterangan yang dilakukan dengan mengadakan pengamatan dan pencatatan secara sistematis terhadap fenomena-fenomena yang sedang dijadikan sasaran pengamatan. Dalam penelitian ini, observasi dilakukan untuk mengamati tingkah laku siswa selama proses pembelajaran berlangsung. Aspek yang dinilai dalam observasi adalah kemampuan siswa dalam mendengarkan penjelasan guru, kemampuan siswa membentuk kelompok yang heterogen, kemampuan siswa dalam bekerja sama dalam kelompok, kemampuan siswa dalam menjawab kuis, dan kemampuan siswa dalam menyampaikan hasil di depan kelas.

Data hasil belajar juga dikumpulkan dengan evaluasi hasil belajar jenis tes. Evaluasi hasil belajar jenis tes merupakan cara untuk melakukan proses penilaian dalam bentuk tugas atau serangkaian tugas yang harus dikerjakan siswa atau sekelompok siswa sehingga menghasilkan suatu nilai yang menggambarkan prestasi siswa. Dalam penelitian ini, tes bertujuan untuk mengukur hasil belajar siswa dengan cara guru memberikan pertanyaanpertanyaan yang harus dijawab atau perintah-perintah yang harus dijalankan oleh siswa pada mata pelajaran IPS, khususnya pada materi koperasi. Tes yang diberikan berupa tes objektif (Siklus I) dan isian (Siklus II). Setelah itu, guru memberikan penilaian terhadap hasil tes yang diperoleh siswa dengan cara menghitung nilai rata-rata kelas dan juga persentase ketuntasan belajar. Nilai yang diperoleh direkap dan dibandingkan antara pratindakan, Siklus I, dan Siklus II.

Data yang dikumpulkan diolah dan dianalisis untuk mengetahui efektifitas dan tingkat keberhasilan suatu tindakan dengan menggunakan uji statistik sederhana. Uji statistik digunakan untuk menghitung nilai rata-rata hasil belajar siswa dan juga untuk menghitung persentase ketuntasan belajar siswa. Selain itu, data juga dianalisis dengan analisis deskriptif.

Indikator keberhasilan dari penelitian tindakan kelas ini adalah peningkatan hasil belajar siswa kelas IV SDN. No. 031/XI Kampung Dalam pada mata pelajaran IPS. Peningkatan hasil belajar siswa mengacu pada Kriteria Ketuntasan Minimum (KKM) mata pelajaran IPS yang telah ditentukan oleh sekolah di awal tahun pelajaran 2016/2017 yaitu sebesar 62,0.

\section{HASIL DAN PEMBAHASAN Pratindakan}

Sebelum memberikan tindakan, guru mengadakan tes penjajakan terlebih dahulu pada siswa. Hasil penelitian menunjukkan bahwa nilai terendah siswa adalah 30,0 dan nilai tertinggi adalah 70,0. Siswa berjumlah 10 orang. Nilai rata-rata berdasarkan uji statistik sederhana adalah 53,0 dengan ketuntasan belajar sebesar $40,0 \%$ (Tabel 1). Nilai rata-rata ini masih termasuk dalam kategori rendah. Siswa yang mendapatkan nilai lebih besar dari KKM kompetensi dasar berjumlah empat orang. Masih terdapat enam orang siswa yang nilainya kurang dari KKM kompetensi dasar. Hasil belajar menjadi indikator dari kesuksesan pembelajaran. Oleh karenanya, hasil belajar yang rendah mendorong guru untuk melakukan penelitian tindakan kelas dengan tujuan 
meningkatkan hasil belajar siswa pada mata pelajaran IPS dengan menggunakan model pembelajaran kooperatif tipe STAD.
Pemberian tindakan diharapkan dapat meningkatkan hasil belajar siswa.

Tabel 1 Hasil tes penjajakan

\begin{tabular}{clccl}
\hline No & \multicolumn{1}{c}{ Nama Siswa } & KKM & Skor & \multicolumn{1}{c}{ Penilaian } \\
\hline 1 & Aulia & 62,0 & 30,0 & Tidak Tuntas \\
2 & Fadhil Herya & 62,0 & 70,0 & Tuntas \\
3 & Imel Putri & 62,0 & 70,0 & Tuntas \\
4 & Ikral Fernandes & 62,0 & 50,0 & Tidak Tuntas \\
5 & M. Andra & 62,0 & 50,0 & Tidak Tuntas \\
6 & Melly Indah & 62,0 & 30,0 & Tidak Tuntas \\
7 & M. Hidayat & 62,0 & 40,0 & Tidak Tuntas \\
8 & Niani Anggraini & 62,0 & 50,0 & Tidak Tuntas \\
9 & Fuji Rahayu & 62,0 & 70,0 & Tuntas \\
10 & Refan Anugrah & 62,0 & 70,0 & Tuntas \\
& Nilai Tertinggi & & 70,0 & \\
& Nilai Terendah & & 30,0 & \\
& Nilai Rata-Rata & & 53,0 & \\
& Ketuntasan Belajar & & $40,0 \%$ & \\
\hline
\end{tabular}

\section{Siklus I}

Penelitian siklus I dilaksanakan pada tanggal 14-21 Februari 2017. Siklus I dibagi 4 (empat) kegiatan yaitu perencanaan, pelaksanaan, pengamatan, dan refleksi. Perencanaan tindakan siklus 1. Tahap perencanaan siklus I meliputi kegiatan yang terdiri atas: menyusun rencana pelaksanaan pembelajaran (RPP), menetapkan bahan ajar untuk siklus I, menyusun skenario pembelajaran dengan menggunakan model pembelajaran STAD, menyusun alat evaluasi untuk mengetahui respon dan hasil kerja siswa pada siklus I, dan menyiapkan lembar observasi untuk melihat bagaimana situasi belajar mengajar ketika model pembelajaran diaplikasikan.

Pelaksanaan tindakan siklus I, terdiri atas: guru mengucapkan salam dan menanyakan keadaan siswa, guru mengecek kehadiran siswa secara klasikal, salah satu siswa memimpin doa, guru mengadakan apersepsi tentang materi pelajaran sebelumnya, guru menyampaikan tujuan pembelajaran, guru menyampaikan skenario pembelajaran yang akan dilaksanakan, siswa dibagi menjadi kelompok-kelompok kecil. setiap kelompok terdiri dari 3-4 siswa yang heterogen, guru menyampaikan inti materi sebagai pengantar dan siswa menyimak penjelasan dari guru. kemudian untuk lebih mendalami materi, siswa mengerjakan lembar kerja kelompok pada kegiatan diskusi kelompok, setelah memberikan pengantar materi guru memberikan lembar kerja kelompok yang harus didiskusikan pada masing-masing kelompok. dengan diskusi siswa saling membantu dalam memahami materi. masing-masing kelompok yang diwakili oleh satu atau dua anggota menyampaikan hasil diskusi kelompok didepan kelas, guru mengevaluasi dengan memberikan kuis atau tes, dan melakukan penilaian terhadap hasil kerja kelompok, guru memberikan penghargaan kepada kelompok yang memperoleh nilai tertinggi, guru bersama siswa membuat kesimpulan pembelajaran, dan guru menyampaikan gambaran materi pelajaran selanjutnya.

Kegiatan pengamatan Siklus I terdiri atas: mengamati aktivitas siswa selama kegiatan pembelajaran dan mencatat 
kejadian-kejadian yang terjadi selama pelaksanaan kegiatan pembelajaran. Selama kegiatan pembelajaran berlangsung, ada beberapa catatan penting yang perlu diperhatian, baik berkaitan dengan proses pembelajaran maupun berkaitan dengan kegiatan guru dan siswa.
Hasil pengamatan siswa pada Siklus I disajikan pada Tabel 2. Secara umum, hasil pengamatan sebagai berikut: kegiatan pembelajaran berjalan seperti biasanya, sebagian kegiatan masih berpusat pada guru, dan sebagian siswa belum berani menjawab kuis dan menyampaikan hasil.

Tabel 2 Hasil pengamatan aktivitas belajar siswa pada akhir Siklus I

\begin{tabular}{clcr}
\hline No & \multicolumn{1}{c}{ Kriteria } & Jumlah & Persentase \\
\hline 1. & Siswa mendengarkan penjelasan guru & 10 & $100,0 \%$ \\
2. & Siswa membentuk kelompok yang heterogen & 7 & $70,0 \%$ \\
3. & Siswa bekerja sama dalam kelompok & 7 & $70,0 \%$ \\
4. & Siswa berani menjawab kuis & 6 & $60,0 \%$ \\
5. & Siswa menyampaikan hasil & 3 & $30,0 \%$ \\
\hline
\end{tabular}

Hasil pengamatan pada Tabel 2 menggambarkan adanya kemajuan yang cukup berarti dalam kegiatan pembelajaran. Hal ini terlihat dari adanya peran dan kepedulian siswa selama proses pembelajaran berlangsung. Sebanyak $70 \%$ siswa sudah mampu bekerja sama. Akan tetapi perlu perbaikan pada kemampuan siswa untuk menjawab kuis dan kemampuan siswa dalam menyampaikan hasil di depan kelas. Dengan demikian pada penerapan model pembelajaran
Student Teams Achievement Division (STAD) pada materi pelajaran berikutnya perlu perbaikan terutama pemberian motivasi siswa untuk mampu bertanya dan menjawab kuis. Agar terlihat sinkronisasi antara keberhasilan di segi proses dengan keberhasilan di segi hasil atau prestasi belajar siswa, berikut ini disajikan hasil analisis nilai siswa diperoleh dari hasil tes formatif pada akhir siklus I. Hasil penelitian pada siklus I disajikan pada Tabel 3.

Tabel 3 Hasil penelitian pada Siklus I

\begin{tabular}{clcll}
\hline No & \multicolumn{1}{c}{ Nama Siswa } & KKM & Skor & \multicolumn{1}{c}{ Penilaian } \\
\hline 1 & Aulia & 62,0 & 50,0 & Tidak Tuntas \\
2 & Fadhil Herya & 62,0 & 80,0 & Tuntas \\
3 & Imel Putri & 62,0 & 70,0 & Tuntas \\
4 & Ikral Fernandes & 62,0 & 70,0 & Tuntas \\
5 & M. Andra & 62,0 & 70,0 & Tuntas \\
6 & Melly Indah & 62,0 & 50,0 & Tidak Tuntas \\
7 & M. Hidayat & 62,0 & 50,0 & Tidak Tuntas \\
8 & Niani Anggraini & 62,0 & 60,0 & Tidak Tuntas \\
9 & Fuji Rahayu & 62,0 & 80,0 & Tuntas \\
10 & Refan Anugrah & 62,0 & 80,0 & Tuntas \\
& Nilai Tertinggi & & 80,0 & \\
& Nilai Terendah & & 50,0 & \\
& Nilai Rata-Rata & & 66,0 & \\
& Ketuntasan Belajar & & $60,0 \%$ & \\
\hline
\end{tabular}

Hasil penelitian yang disajikan pada Tabel 3 menunjukkan bahwa nilai terendah siswa adalah 50,0 dan nilai tertinggi yang dicapai siswa adalah 80,0. Nilai rata-rata 
sebesar 66,0. Nilai rata-rata pada siklus I meningkat jika dibandingkan dengan nilai rata-rata pada saat pratindakan. Saat pratindakan, nilai rata-rata siswa sebesar 53,0 yang kemudian meningkat menjadi 66,0 setelah pemberian tindakan siklus I. Selain nilai rata-rata, peningkatan juga terjadi pada ketuntasan belajar. Ketuntasan belajar siswa pada saat pratindakan sebesar $40,0 \%$ yang kemudian meningkat menjadi $60,0 \%$ pada siklus I. Hasil ini mengindikasikan bahwa penggunaan model pembelajaran kooperatif tipe STAD membawa pengaruh yang baik terhadap hasil belajar siswa.

Berdasarkan hasil, guru melakukan refleksi. Kegiatan refleksi terdiri atas: menganalisis data hasil pelaksanaan tindakan, mengevaluasi pelaksanaan tindakan yang telah dilakukan pada siklus I, dan menyusun rencana tindakan untuk siklus II. Refleksi dari hasil penelitian adalah sebagai berikut:

a. Peningkatan hasil belajar sudah mulai terlihat baik dari nilai rata-rata maupun dari ketuntasan belajar. Dengan demikian, pemberian tindakan perlu dilanjutkan.

b. Hasil observasi menunjukkan bahwa siswa belum berani untuk menjawab kuis dan menyampaikan hasil di depan kelas. Dengan demikian, guru perlu melakukan pendekatan personal dengan siswa yang mengalami kesulitan tersebut dan juga memberikan motivasi pada siswa.

c. Berdasarkan hasil siklus I, guru perlu melakukan perbaikan dalam pelaksanaan pembelajaran pada Siklus II.

\section{Siklus II}

Penelitian siklus II dilaksanakan pada tanggal 7-17 Maret 2017. Siklus II terdiri atas 4 (empat) kegiatan yaitu perencanaan, pelaksanaan, pengamatan, dan refleksi. Tahap perencanaan siklus I meliputi kegiatan yang terdiri atas: menyusun rencana pelaksanaan pembelajaran (RPP), menetapkan bahan ajar untuk siklus II, menyusun skenario pembelajaran dengan menggunakan model pembelajaran STAD, menyusun alat evaluasi untuk mengetahui respon dan hasil kerja siswa pada siklus II, dan menyiapkan lembar observasi untuk melihat bagaimana situasi belajar mengajar ketika model pembelajaran diaplikasikan.

Pelaksanaan tindakan siklus II, terdiri atas: guru mengucapkan salam dan menanyakan keadaan siswa, guru mengecek kehadiran siswa secara klasikal, salah satu siswa memimpin doa, guru mengadakan apersepsi tentang materi pelajaran sebelumnya, guru menyampaikan tujuan pembelajaran, guru menyampaikan skenario pembelajaran yang akan dilaksanakan, siswa dibagi menjadi kelompok-kelompok kecil. setiap kelompok terdiri dari 3-4 siswa yang heterogen, guru menyampaikan inti materi sebagai pengantar dan siswa menyimak penjelasan dari guru. kemudian untuk lebih mendalami materi, siswa mengerjakan lembar kerja kelompok pada kegiatan diskusi kelompok, setelah memberikan pengantar materi guru memberikan lembar kerja kelompok yang harus didiskusikan pada masing-masing kelompok. dengan diskusi siswa saling membantu dalam memahami materi. masing-masing kelompok yang diwakili oleh satu atau dua anggota menyampaikan hasil diskusi kelompok didepan kelas, guru mengevaluasi dengan memberikan kuis atau tes, dan melakukan penilaian terhadap hasil kerja kelompok, guru memberikan penghargaan kepada kelompok yang memperoleh nilai tertinggi, guru bersama siswa membuat kesimpulan pembelajaran, dan guru menyampaikan gambaran materi pelajaran selanjutnya.

Kegiatan pengamatan siklus II terdiri atas: mengamati aktivitas siswa selama kegiatan pembelajaran dan mencatat kejadian-kejadian yang terjadi selama pelaksanaan kegiatan pembelajaran. 
Selama kegiatan pembelajaran berlangsung, ada beberapa catatan penting yang perlu diperhatian, baik berkaitan dengan proses pembelajaran maupun berkaitan dengan kegiatan guru dan siswa. Secara umum, hasil pengamatan menunjukkan bahwa seluruh siswa telah mendengar penjelasan guru dan siswa juga telah membentuk kelompok yang heterogen. Sebagian besar siswa telah mampu bekerja sama dalam kelompok, berani menjawab kuis, dan berani menyampaikan hasil di depan kelas. Hasil pengamatan siswa pada Siklus II disajikan pada Tabel 4.

Tabel 4 Hasil pengamatan aktivitas belajar siswa pada akhir Siklus II

\begin{tabular}{clcc}
\hline No & \multicolumn{1}{c}{ Kriteria } & Jumlah & Persentase \\
\hline 1. & Siswa mendengarkan penjelasan guru & 10 & $100,0 \%$ \\
2. & Siswa membentuk kelompok yang heterogen & 10 & $100,0 \%$ \\
3. & Siswa bekerja sama dalam kelompok & 8 & $80,0 \%$ \\
4. & Siswa berani menjawab kuis & 8 & $80,0 \%$ \\
5. & Siswa menyampaikan hasil & 80 & $80,0 \%$ \\
\hline
\end{tabular}

Hasil penelitian pada siklus II disajikan pada Tabel 5. Hasil penelitian menunjukkan bahwa nilai terendah siswa adalah 60,0 dan nilai tertinggi yang dicapai siswa adalah 90,0. Nilai rata-rata sebesar 79,0. Nilai rata-rata pada siklus II meningkat jika dibandingkan dengan nilai rata-rata pada saat pratindakan. Saat pratindakan, nilai rata-rata siswa sebesar 53,0 yang kemudian meningkat menjadi 66,0 setelah pemberian tindakan siklus I, dan kembali meningkat menjadi 79,0 pada siklus II. Selain nilai rata-rata, peningkatan juga terjadi pada ketuntasan belajar. Ketuntasan belajar siswa pada saat pratindakan sebesar 40,0\% yang kemudian meningkat menjadi $60,0 \%$ pada siklus I, dan kembali meningkat menjadi 90,0\% pada siklus II. Hasil ini mengindikasikan bahwa penggunaan model pembelajaran kooperatif tipe STAD membawa pengaruh yang baik terhadap hasil belajar siswa. Hasil belajar IPS pada siswa kelas IV SDN. No. 031/XI Kampung Dalam semakin baik setelah guru menggunakan model pembelajaran kooperatif tipe STAD.

Tabel 5 Hasil penelitian pada Siklus II

\begin{tabular}{clccl}
\hline No & \multicolumn{1}{c}{ Nama Siswa } & KKM & Nilai & \multicolumn{1}{c}{ Keterangan } \\
\hline 1 & Aulia & 62,0 & 80,0 & Tuntas \\
2 & Fadhil Herya & 62,0 & 80,0 & Tuntas \\
3 & Imel Putri & 62,0 & 90,0 & Tuntas \\
4 & Ikral Fernandes & 62,0 & 80,0 & Tuntas \\
5 & M. Andra & 62,0 & 80,0 & Tuntas \\
6 & Melly Indah & 62,0 & 70,0 & Tuntas \\
7 & M. Hidayat & 62,0 & 60,0 & Tidak Tuntas \\
8 & Niani Anggraini & 62,0 & 70,0 & Tuntas \\
9 & Fuji Rahayu & 62,0 & 90,0 & Tuntas \\
10 & Refan Anugrah & 62,0 & 90,0 & Tuntas \\
& Nilai Tertinggi & & 90,0 & \\
& Nilai Terendah & & 60,0 & \\
& Nilai Rata-Rata & & 79,0 & \\
& Ketuntasan Belajar & \multicolumn{3}{c}{} \\
\hline
\end{tabular}


Berdasarkan hasil, guru melakukan refleksi. Kegiatan refleksi terdiri atas: menganalisis data hasil pelaksanaan tindakan, mengevaluasi pelaksanaan tindakan yang telah dilakukan pada siklus I, dan menyusun rencana tindakan untuk siklus II. Refleksi dari hasil penelitian adalah sebagai berikut:

a. Aktivitas dan hasil belajar siswa semakin membaik sehingga Siklus penelitian dihentikan. Guru sebaiknya tetap melanjutkkan penggunaan model ini untuk meningkatkan aktivitas dan hasil belajar siswa.

b. Guru perlu memberikan stimulus khusus untuk siswa yang belum mampu bekerja sama dalam kelompok, menjawab kuis, dan menyampaikan hasil.

c. Guru juga sebaiknya meningkatkan pengetahuan tentang model pembelajaran yang dapat diaplikasikan dalam kegiatan pembelajaran. Model yang digunakan hendaknya bervariasi agar pembelajaran tidak monoton.

\section{Analisis Hasil Belajar}

Hasil belajar merupakan salah satu indikator dari proses belajar. Hasil belajar adalah perubahan perilaku uyang diperoleh siswa setelah mengalami aktivitas belajar (Anni, 2004). Hasil belajar juga dapat diartikan sebagai kemampuan yang diperoleh individu setelah proses belajar berlangsung, yang dapat memberikan perubahan tingkah laku baik pengetahuan, pemahaman, sikap dan keterampilan siswa sehingga menjadi lebih baik dari sebelumnya. Menurut Hamalik (2004), hasil belajar adalah tingkat penguasaan yang dicapai oleh pelajar dalam mengikuti proses belajar mengajar sesuai dengan tujuan pendidikan yang ditetapkan. Hasil belajar juga dapat didefinisikan sebagai hasil dari suatu interaksi tindak belajar dan tindak mengajar (Dimyati dan Mudjiono, 2013). Dari sisi guru, tindak mengajar diakhiri dengan proses evaluasi hasil belajar, sedangkan dari sisi siswa, hasil belajar merupakan berakhirnya penggal dan puncak proses belajar. Winkel (2009) mengemukakan bahwa hasil belajar merupakan bukti keberhasilan yang telah dicapai oleh seseorang. Hasil belajar merupakan pengukuran dari penilaian kegiatan belajar atau proses belajar yang dinyatakan dalam symbol, huruf maupun kalimat yang menceritakan hasil yang sudah dicapai oleh setiap siswa pada periode tertentu.

Dalam penelitian ini, hasil belajar siswa dinilai dari nilai rata-rata kelas dan persentase ketuntasan belajar siswa. Hasil penelitian menunjukkan bahwa pada saat pratindakan sebesar 53,0 dengan ketuntasan belajar sebesar 40,0\%. Hasil ini menunjukkan bahwa hanya ada empat dari sepuluh siswa yang memiliki nilai lebih besar dari KKM kompetensi dasar dengan nilai KKM sebesar 62,0. Hasil belajar yang rendah mendorong guru untuk melakukan penelitian tindakan kelas. Penelitian tindakan kelas dilakukan dalam dua siklus (Siklus I dan Siklus II). Tindakan yang diberikan dalam penelitian ini adalah penerapann model pembelajaran kooperatif tipe STAD.

Setelah melaksanakan tindakan Siklus I, guru kembali mengevaluasi hasil belajar siswa. Hasil belajar siswa pada Siklus I meningkat dibandingkan dengan hasil belajar pada saat pratindakan. Nilai ratarata pada evaluasi hasil belajar Siklus I sebesar 66,0 dengan persentase ketuntasan belajar sebesar 60,0\%. Hasil ini mengindikasikan bahwa terjadi peningkatan nilai rata-rata kelas dari 53,0 menjadi 66,0. Selain itu, jumlah siswa yang memenuhi KKM kompetensi dasar juga meningkat dari empat orang menjadi enam orang. Dengan demikian, hasil ini mendorong guru untuk melanjutkan tindakan pada Siklus II. Hasil belajar siswa pada Siklus II meningkat dibandingkan dengan hasil belajar pada saat pratindakan dan Siklus I. Nilai rata-rata pada evaluasi 
hasil belajar Siklus II sebesar 79,0 dengan persentase ketuntasan belajar sebesar 90,0\%. Hasil ini mengindikasikan bahwa terjadi peningkatan nilai rata-rata kelas dari 53,0 pada saat pratindakan meningkat menjadi 66,0 pada Siklus I, dan kembali meningkat menjadi 79,0 pada Siklus II.
Selain itu, jumlah siswa yang memenuhi KKM kompetensi dasar juga meningkat dari enam orang menjadi sembilan orang. Rekapitulasi hasil belajar siswa pada saat pratindakan, siklus I, dan siklus II disajikan pada Gambar 1.

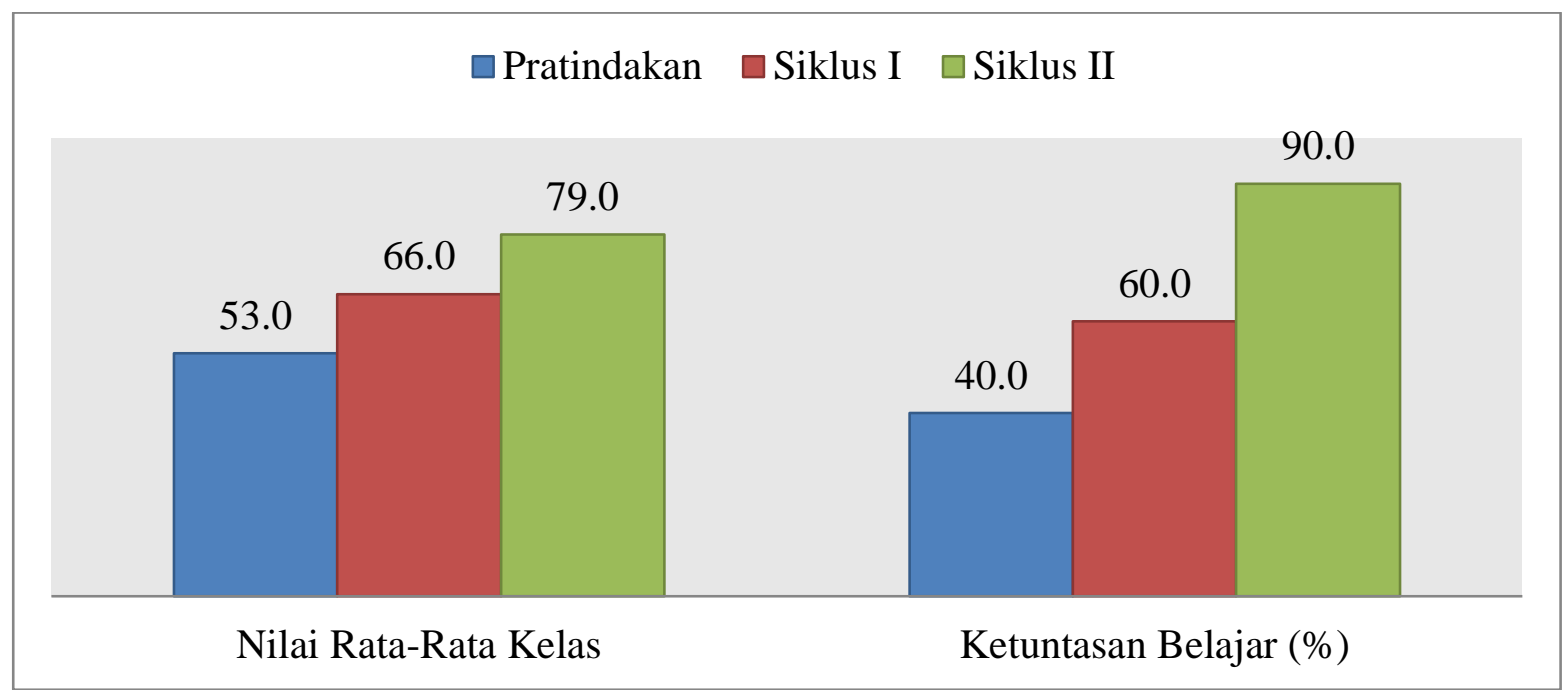

Gambar 1 Rekapitulasi hasil belajar siswa pada saat pratindakan, siklus I, dan siklus II

Hasil penelitian menunjukkan bahwa model pembelajaran kooperatif tipe Student Teams Achievement Division dapat meningkatkan hasil belajar IPS tentang koperasi pada siswa kelas IV di SDN. No. 031/XI Kampung Dalam tahun 2016/2017. Hasil penelitian ini mendukung hasil penelitian Mangentje (2013) yang telah menemukan penerapan model kooperatif tipe STAD dapat meningkatkan hasil belajar siswa dalam pembelajaran IPS Kelas IV SDN Silampayang. Hasil penelitian ini juga mendukung hasil penelitian Darusalam (2013) yang telah menemukan penerapan model kooperatif tipe STAD dapat meningkatkan hasil belajar siswa dalam pembelajaran IPS di Kelas V SDN Inpres Tabing Kecamatan Peling Tengah Kabupaten Banggai Kepulauan. Mutalib (2014) juga menemukan hasil yang sama bahwa penerapan model kooperatif tipe STAD dapat meningkatkan hasil belajar siswa kelas V Sekolah Dasar Negeri 15 Sungai Laur Kabupaten Ketapang.

Temuan ini juga semakin menguatkan hasil penelitian Pantanemo, Saneba, dan Palimbong (2014) yang menyatakan bahwa pembelajaran kooperatif tipe STAD dapat digunakan untuk meningkatkan hasil belajar siswa pada pembelajaran IPS di Kelas IV SDN Inpres Kautu. Temuan ini juga menguatkan temuan Gusniar (2014) yang mengemukakan bahwa penerapan model pembelajaran kooperatif tipe Student Teams Achievment Division (STAD) dapat meningkatkan hasil belajar siswa pada mata pelajaran IPS di kelas IV SDN No. 2 Ogoamas II.

Hasil penelitian ini juga mendukung hasil penelitian Jatimah (2016) bahwa aktivitas dan hasil belajar IPS meningkat dengan penerapan pembelajaran kooperatif tipe STAD variasi permainan nagawan pada siswa kelas V SD Negeri Perumnas. Temuan ini juga mendukung temuan Jasman (2016) yang menyatakan bahwa 
terjadi peningkatan hasil belajar IPS melalui pembelajaran kooperatif tipe (STAD) pada siswa kelas V SDN Saladang Kecamatan Lampasio. Hasil penelitian ini juga menguatkan temuan dari Widiyati (2016) bahwa model pembelajaran kooperatif tipe STAD dapat meningkatkan aktivitas dan hasil belajar IPS siswa kelas IV SDN 1 Kresnowidodo Kabupaten Pesawaran tahun pelajaran 2015/2016.

\section{SIMPULAN}

Aktivitas belajar siswa semakin membaik. Seluruh siswa telah mendengar penjelasan guru dan membentuk kelompok yang heterogen. Sebagian besar siswa juga telah dapat bekerja sama dalam kelompok, menjawab kuis, dan menyampaikan hasil. Penggunaan model pembelajaran kooperatif tipe STAD berhasil meningkatkan hasil belajar siswa yang dilihat dari peningkatan nilai rata-rata dan ketuntasan belajar. Nilai rata-rata meningkat dari 53,0 pada pratindakan menjadi 66,0 pada siklus I dan kembali meningkat menjadi 79,0 pada siklus II. Demikian juga halnya dengan ketuntasan belajar. Ketuntasan belajar meningkat dari 40,0 pada pratindakan menjadi 60,0 pada siklus I dan kembali meningkat menjadi 90,0 pada siklus II.

Berdasarkan hasil, penelitian ini menyarankan guru untuk memberikan stimulus khusus pada siswa yang masih termasuk dalam kategori belum tuntas. Stimulus tersebut diharapkan dapat membuat siswa menjadi lebih tertarik mengikuti kegiatan pembelajaran. Disamping itu, guru juga perlu mengingatkan siswa untuk mempersiapkan diri lebih baik lagi sebelum mengikuti skenario pembelajaran. Guru juga perlu menyampaikan tujuan dan manfaat pembelajaran dengan lebih lugas. Guru juga perlu memberian stimulus untuk merangsang ingatan terhadap materi pelajaran sebelumnya, stimulus tersebut perlu mengacu kepada hasil tes yang mengukur perubahan tingkah laku yang dituangkan di rencana pelaksanaan pembelajaran. Guru juga perlu memberikan penguatan dengan cara pemberian tugas dan latihan.

\section{DAFTAR PUSTAKA}

Anni, C. T. 2004. Psikologi Belajar (Semarang: IKIP Semarang Press

Darusalam, M. 2013. Meningkatkan Hasil Belajar Siswa pada Mata Pelajaran IPS dengan Menggunakan Model Pembelajaran Kooperatif Tipe STAD di Kelas V SDN Inpres Tabing Kecamatan Peling Tengah Kabupaten Banggai Kepulauan. Jurnal Kreatif Tadulako Online, Vol. 1 No.1, 1-15.

Dimyati dan Mudjiono. 2013. Belajar dan Pembelajaran. Cetakan kelima. Jakarta: Rineka Cipta.

Gusniar. 2014. Penerapan Model Pembelajaran Kooperatif Tipe Student Teams Achievment Division (STAD) Dalam Meningkatkan Hasil Belajar Siswa Pada Mata Pelajaran IPS Kelas IV SDN No. 2 Ogoamas II. Jurnal Kreatif Tadulako Online, Vol. 2 No. 1, 198-221.

Hamalik, O. 2004. Kurikulum dan Pembelajaran. Jakarta: Bumi Aksara.

Jasman. 2016. Peningkatan Hasil Belajar IPS Pada Materi Perjuangan Melawan Penjajah dan Pergerakan Nasional Indonesia Melalui Pembelajaran Kooperatif Tipe (STAD) Pada Siswa Kelas V SDN Saladang Kecamatan Lampasio. Jurnal Kreatif Tadulako Online, Vol. 4 No. 11, 69-82.

Jatimah. 2016. Peningkatan Aktivitas dan Hasil Belajar IPS Melalui Pembelajaran Kooperatif Tipe STAD Variasi Permainan Nagawan Pada Siswa Kelas V SD Negeri Perumnas. Jurnal Kreatif Tadulako Online, Vol. 4 No. 10, 282-288. 
Mangentje, Y. M. 2013. Penerapan Model Kooperatif Tipe STAD (Student Team Achievement Division) untuk Meningkatkan Hasil Belajar Siswa dalam Pembelajaran IPS Kelas IV SDN Silampayang. Jurnal Kreatif Tadulako Online, Vol. 1 No. 3, 106117.

Mutalib, D. 2014. Peningkatan Hasil Belajar Ips Model Pembelajaran Kooperatif Tipe STAD di Sekolah Dasar [Skripsi]. Pontianak: Program Studi Pendidikan Guru Sekolah Dasar, Jurusan Pendidikan Dasar, Fakultas Keguruan dan Ilmu Pendidikan, Universitas Tanjungpura.

Pantanemo, D., Saneba, B., \& Palimbong. A. 2014. Pembelajaran Kooperatif Tipe STAD Untuk Meningkatkan Hasil Belajar Siswa pada Pembelajaran IPS di Kelas IV SDN Inpres Kautu. Jurnal Kreatif Tadulako Online, Vol. 2 No. 2, 3241.Purwanto. 2014. Evaluasi Hasil Belajar. Yogyakarta: Pustaka Pelajar.

Rusman. 2011. Model- Model Pembelajaran. Jakarta:PT Raja Grafindo Persada.

Sapriya. 2011. Pendidikan IPS. Bandung: Remaja Rosdakarya

Slavin, R.E. 2008. Cooperative Learning: Teori, Riset, dan Praktek. Narulita, Y., penerjemah. Bandung: Nusa Media. Terjemahan dari: Cooperative Learning: Theory, Research, and Practice.

Trianto. 2007. Model-model Pembelajaran Inovatif Berorientasi Kontruktivistik. Jakarta: Prestasi Pustaka.

Umiarso. 2011. Pendidikan Pembebasan. Yogyakarta: Ar- Ruzz Media.

Widiyati, T. 2016. Peningkatan Aktivitas dan Hasil Belajar IPS Melalui Pembelajaran Kooperatif Tipe STAD Siswa Kelas IV SD Negeri 1 Kresnowidodo Kabupaten Pesawaran Tahun Pelajaran 2015/2016 [Skripsi].
Bandar Lampung: Fakultas Keguruan Dan Ilmu Pendidikan, Universitas Lampung.

Winkel, W. S. 2009. Psikologi Pengajaran. Yogyakarta: Media abadi. 